\title{
USING RED ONCOM (NEUROSPORA SITOPHILA SPP) \\ AND BLACK ONCOM (RHIZOPUS OLIGOSPORUS) IN FEED FORMULATION ON PERFORMANCE AND INTESTINAL PROPERTIES OF BROILER
}

\author{
Danung Nur Adli ${ }^{1)}$ and Osfar Sjofjan ${ }^{1)}$ \\ 1) Animal Nutrition Department, Animal Science Faculty, University of Brawijaya, East Java, Indonesia, 65145 \\ Email: danungnuradli1994@gmail.com
}

\begin{abstract}
The purpose of this research was to determine the dietary effect of red oncom (Neurospora sitophila spp) and black oncom (Rhizopus oligosporus) on performance and intestinal properties of broiler in different levels. The materials used for this research were 100 unsex broiler (20 days old) with Lohmann strain. Method was used in this experiment was Completely Randomize Design with 5 treatments and 4 replications. The treatment were as follows, T0: basal diet without additive, T1: basal diet $+(0.25 \%$ red oncom (Neurospora sitophila spp) and $0.25 \%$ black oncom (Rhizopus oligosporus), P2: basal diet $+(0.5 \%$ red oncom (Neurospora sitophila spp) and 0.5\% black oncom (Rhizopus oligosporus), T3: basal diet $+(0.5 \%$ red oncom (Neurospora sitophila spp) and $0.25 \%$ black oncom (Rhizopus oligosporus), and T4: basal diet $+(0.75 \%$ red oncom (Neurospora sitophila spp) and $0.5 \%$ black oncom (Rhizopus oligosporus). The result showed that red oncom (Neurospora sitophila spp) and black oncom (Rhizopus oligosporus) has significantly enhanced ( $p<0.05)$ on intestinal properties. It can be concluded that red oncom (Neurospora sitophila spp) and black oncom (Rhizopus oligosporus) in feed gives a positive result on the broiler intestinal properties.
\end{abstract}

Keywords: Fermentation, crypt depth, tempeh, villus height

How to Cite:

Adli, D. N., \& Sjofjan, O. (2021). Using Red Oncom (Neurospora Sitophila spp) and Black Oncom (Rhizopus Oligosporus) in feed formulation on Performance and Intestinal Properties of Broiler. Jurnal Nutrisi Ternak Tropis 4 (2) 70-76
*Corresponding author:

Danung Nur Adli

Email: danungnuradli1994@gmail.com

Animal Science Faculty, University of Brawijaya,

East Java, Indonesia, 65145 


\section{INTRODUCTION}

Oncom is a traditional food Indonesia from Java West (Agustiningsih, 2002). Oncom is a source of nutrition potential for society, because with the fermentation process, then the structure chemical materials that were complex, will break down into compounds simpler ones so more easily digested and utilized by body (Koni $e t$ al., 2013; Hidanah and Widjaja, 2010; Babu et al., 2009). Waste are derivation by product of processing that still containing a lot nutrient (Putri and Setiawati, 2008). Therefore, it is necessary to use that red oncom (Neurospora sitophila spp) and black oncom (Rhizopus oligosporus) as broiler feed. The advantage of using red oncom (Neurospora sitophila spp) and black oncom (Rhizopus oligosporus) is a high starch content (Amalie, 2019).

Currently there are two types of oncom, namely red and black oncom. Second difference the type of oncom lies in the type the microbial. Oncom red is produced by $N$. sitophila microbes that have strains red. While black oncom is produced by $R$. oligosporus microbes that have black strain (Mahfudz, 2006; Zaman, 2013). Red or black oncom is determined by color pigments produced by microbes that are used in the fermentation process. Microbes' oncom can secrete lipase and enzymes proteases that are active during the fermentation process and plays an important role in decomposition of starch into sugar (Adli et al., 2018).

However, animal feed sourced from waste has a low nutritional value that is high in crude fiber, low nutritional energy and crude protein being a limiting factor in its use. Previous studies explain the increase in crude fiber content in feed which accelerates the flow of diets in the digestive tract to be fast (Adli and Sjofjan, 2018). Provision of agricultural waste is not negative on growth, feed consumption and Feed Convertion Ratio (Adli et al., 2019).

\section{MATERIAL AND METHODS}

A total of 100 (male and females) oneday-old Lohmann broiler were randomly allocated to 5 dietary treatments and 4 replicates. The cage that is used using a stage cage consists of 20 flocks. Each flock cage is filled with 5 Lohmann broiler aged 20 days, the cage is equipped with a place to drink and feed. The food and drinking water used in the study was administered adlibitum. Red oncom (Neurospora sitophila spp) and black oncom (Rhizopus oligosporus) is obtained from Tasikmalaya, Regency, and West Java Indonesia which through several processes include counting the oncom, drying, and grinding it into flour.

\section{Experimental design}

The method used in this study was a field experiment with a completely randomized design (CRD) with 5 treatments and 4 replications and each of them consisted of 5 broilers. The treatments given are T0: base formulated feed without oncom, T1: base formulated feed $+(0.25 \%$ red oncom (Neurospora sitophila spp) and $0.25 \%$ black oncom (Rhizopus oligosporus), T2: basal diet $+(0.5 \%$ red oncom (Neurospora sitophila spp) and $0.5 \%$ black oncom (Rhizopus oligosporus), T3: basal diet $+(0.5 \%$ red oncom (Neurospora sitophila spp) and $0.25 \%$ black oncom (Rhizopus oligosporus), and T4: basal diet $+(0.75 \%$ red oncom (Neurospora sitophila spp) and $0.5 \%$ black oncom (Rhizopus oligosporus). The formulation of feedstuff consisted: maize, dehulled soya bean meal, L-lysine, DL-Methionine, Di calcium Phosphate, Premix mineral, vitamin mineral, choline, limestone, soyoil, and oncom. Feed was reformulation using software.

\section{Data analysis}

Data were subjected using SAS Academic online, if there is differences among treatments $(p<0.05)$ were continued using Duncan multiple range test (Albright et al., 2011) 
Table 1. Ingredient and nutrient composition of the diet

\begin{tabular}{lcc}
\hline Feed nutrient & Starter (1-21 days) & Finisher (22-35days) \\
\hline Maize & 57.11 & 69.66 \\
Dehulled soybean meal & 36.53 & 26.65 \\
L-Lysine & 0.1 & 0.1 \\
DL-methionine & 0.55 & 0.55 \\
Dicalcium phosphate & 1.67 & 1.55 \\
Limestone & 1.13 & 1.02 \\
Salt & 0.3 & 0.3 \\
Soy oil & 2.81 & 0.06 \\
Vitamin premix* & 0.05 & 0.05 \\
Mineral premix** & 0.05 & 0.05 \\
Choline & 0.1 & 0.1 \\
\hline & 100 & 100 \\
\hline Dry matter $(\%)$ & 87.00 & 87.00 \\
ME (Kcal/kg) & 3050 & 3150 \\
Ash $(\%)$ & 9.00 & 9.00 \\
Crude protein $(\%)$ & 22.00 & 18.00 \\
Fat $(\%)$ & 6.00 & 6.00 \\
Crude fibre $(\%)$ & 3.00 & 2.50 \\
\hline base formuled & &
\end{tabular}

T0: base formulated feed without oncom,

$\mathrm{T} 1$ : basal diet $+(0.25 \%$ red oncom (Neurospora sitophila spp) and $0.25 \%$ black oncom (Rhizopus oligosporus),

T2: basal diet $+(0.5 \%$ red oncom (Neurospora sitophila spp) and $0.5 \%$ black oncom (Rhizopus oligosporus),

T3: basal diet $+(0.5 \%$ red oncom (Neurospora sitophila spp) and $0.25 \%$ black oncom (Rhizopus oligosporus), and T4: basal diet $+(0.75 \%$ red oncom (Neurospora sitophila spp) and $0.5 \%$ black oncom (Rhizopus oligosporus).

\section{Performance measurement}

The broiler performance were calculated every week on weight gain. Feed gain ratio were calculated amount feed consumption a certain period. Each week are calculated on body weight gain at 0 , 7,14,21,35 days. (Sjofjan et al., 2019).

\section{Intestinal measurement}

Intestinal measurement were sample taken from intestinal approximately $12 \mathrm{~cm}$ of duodenum, jejunum, and ileum. Moreover, Hematoxylin eosin staining are conducted to recorded the sample result.

\section{RESULTS AND DISCUSSION}

Data on comparation red oncom (Neurospora sitophila spp) and black oncom (Rhizopus oligosporus) in feed showed in Table 2. Giving Red oncom (Neurospora sitophila spp) and black oncom (Rhizopus oligosporus) meal doesn't improved ( $p>$ $0.05)$ on FI, FCR, and BWG. Sjofjan et al (2020) explained that the body weight of poultry to be determined would be determined by the consumption of feed with a balanced energy and protein content. The description proves the fermentation product with carotenogenic mold Neurospores have good nutritional value and can be utilized as a well-marked source of poultry nutrition with the same productivity as the treatment control or increase, so it can be used as alternative feed ingredients to replace some conventional feed.

Result of crypth depth are reflected from amount feed inside (Widiyawati et al 2020). Statistical analysis of the meat quality presented in table 3 . Shows that red oncom (Neurospora sitophila spp) and black oncom (Rhizopus oligosporus) in feed on the intestinal properties in villus height and 
crypt depth $(p<0.05)$ on broiler. Villus height in jejunum tissue increase is a positive indicator of intestinal health and increased of absortive area.

The level addition of a probiotic to broiler increased the villus height leading to increased intestinal surface area and therefore to an increased digestion and absorption of nutrients in the basal diet. Thus, the increasing of villus height theorically from decreased intestinal cell turnover and gene expression (Sujono, 2001). According to Sjofjan et al (2020) factors that affect heart weight are broiler body weight, age, broiler activity and gender. A shallow crypth is positive factors for development of an immunal status and efficient for small intestine. With a lower renewal rate, the cells in the intestinal become mature and allowing more efficient digestive enzyme production and absorption (Kasiman, 2019). A variety of indigenous fermented foods exist today; however, oncom has been one of the most widely accepted mold-modified fermented products.

Table 2. Effect of red oncom (Neurospora sitophila spp) and black oncom (Rhizopus oligosporus) in feed on the performance

\begin{tabular}{lccccccc}
\hline Item & T0 & T1 & T2 & T3 & T4 & SEM & $p$ value \\
\hline FI, g/bird & 2668 & 2810.8 & 2690.80 & 2499 & 2810.80 & 42.10 & 1.26 \\
FCR & 1.48 & 1.54 & 1.58 & 1.49 & 1.45 & 0.37 & 0.03 \\
BWG, g/bird & 1720.33 & 1717 & 1698.86 & 1594.64 & 1576.78 & 21.33 & 0.34 \\
\hline
\end{tabular}

a-b Means within row followed by different superscript differ at $p<0.05$, BWG (body weight gain), FI (feed intake), FCR (feed conversion ratio), BWG (body weight gain)
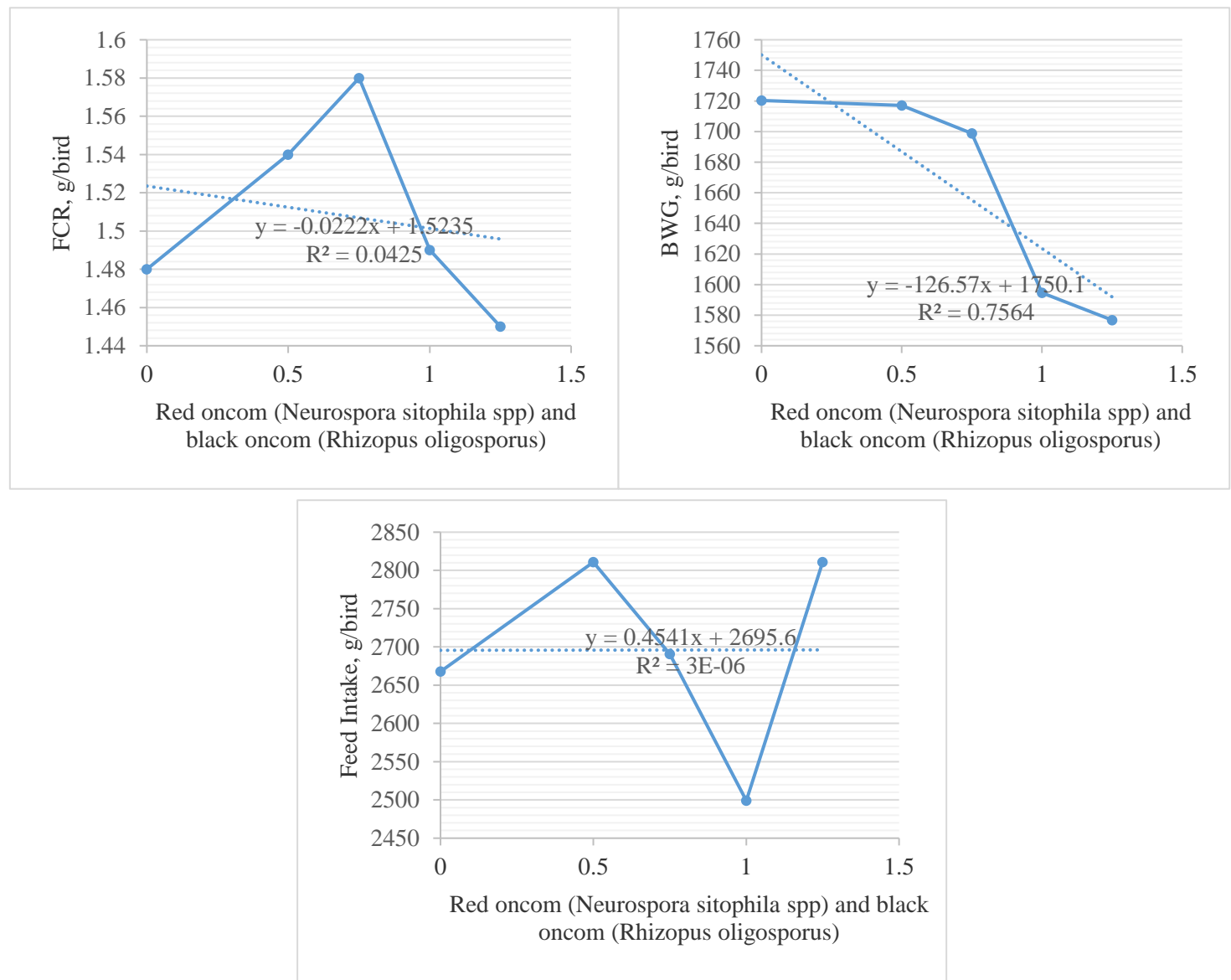

Ingredients (Mahfudz, 2006).

Figure 2. Effect of Effect of red oncom (Neurospora sitophila spp) and black oncom (Rhizopus oligosporus) on FCR and BWG 
Table 3. Effect of red oncom (Neurospora sitophila spp) and black oncom (Rhizopus oligosporus) in feed on the intestinal properties

\begin{tabular}{lccccccc}
\hline Item & P0 & P1 & P2 & P3 & P4 & SEM & $p$ value \\
\hline Villus height, $\mu \mathrm{m}$ & $432.25^{\mathrm{c}}$ & $494.25^{\text {bc }}$ & $563.50^{\mathrm{ab}}$ & $573.25^{\mathrm{a}}$ & $572.5^{\mathrm{a}}$ & 5.14 & 0.25 \\
Crypth depth $\mu \mathrm{m}$ & $133.75^{\mathrm{bc}}$ & $158.75^{\mathrm{a}}$ & $152.50^{\mathrm{ab}}$ & $153.50^{\mathrm{ab}}$ & $157.75^{\mathrm{a}}$ & 2.82 & 0.73 \\
VH/CD & 5.57 & 7.06 & 6.35 & 6.06 & 5.23 & 0.63 & 0.24 \\
\hline
\end{tabular}

${ }^{\mathrm{a}-\mathrm{b}}$ Means within row followed by different superscript differ at $p<0.05$

Oncom is a local resources feed produced by fermentation process, with good of protein and nutritious are good (Vital et al., 2018). It also has a high content of carbohydrates, calories, and a good sourceof fibers, being an excellent product for energy intake, and if inserted in a balanced diet, it may act as intestinal

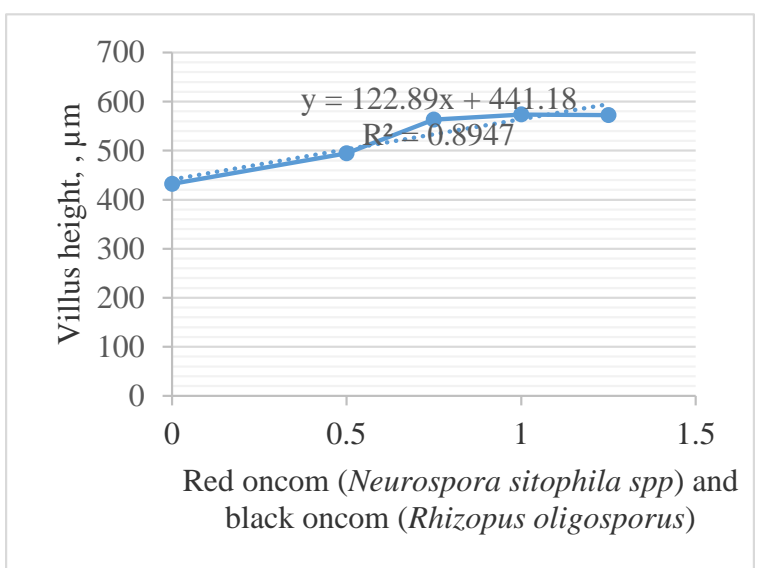

regulator (Kasiman, 2019). Continuous scientific research is necessary to identify beneficial components, their mechanisms of action, function, nutritional aspects (Vital et al., 2018). Oncom can be produced by using local or native beans, giving alternative to specific feed (Mahfudz, 2006; Zaman, 2013).

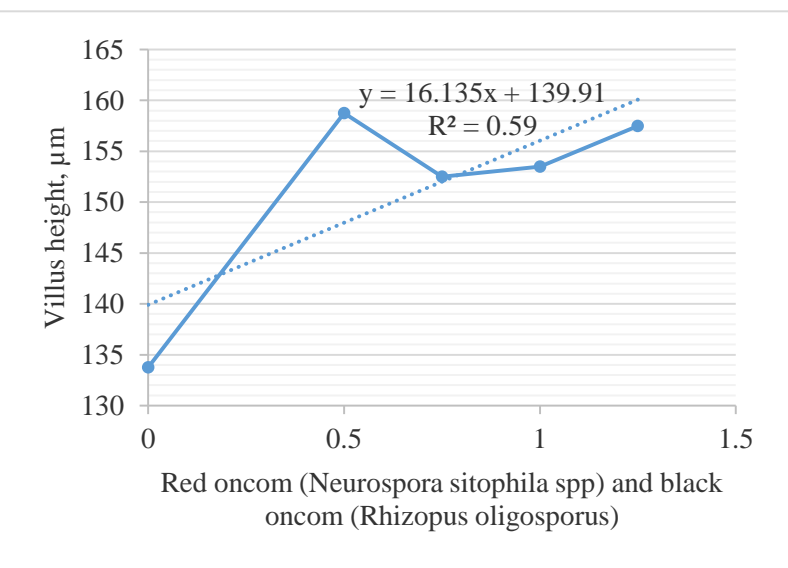

Figure 4. Effect of red oncom (Neurospora sitophila spp) and black oncom (Rhizopus oligosporus) on Villus height, $\mu \mathrm{m}$

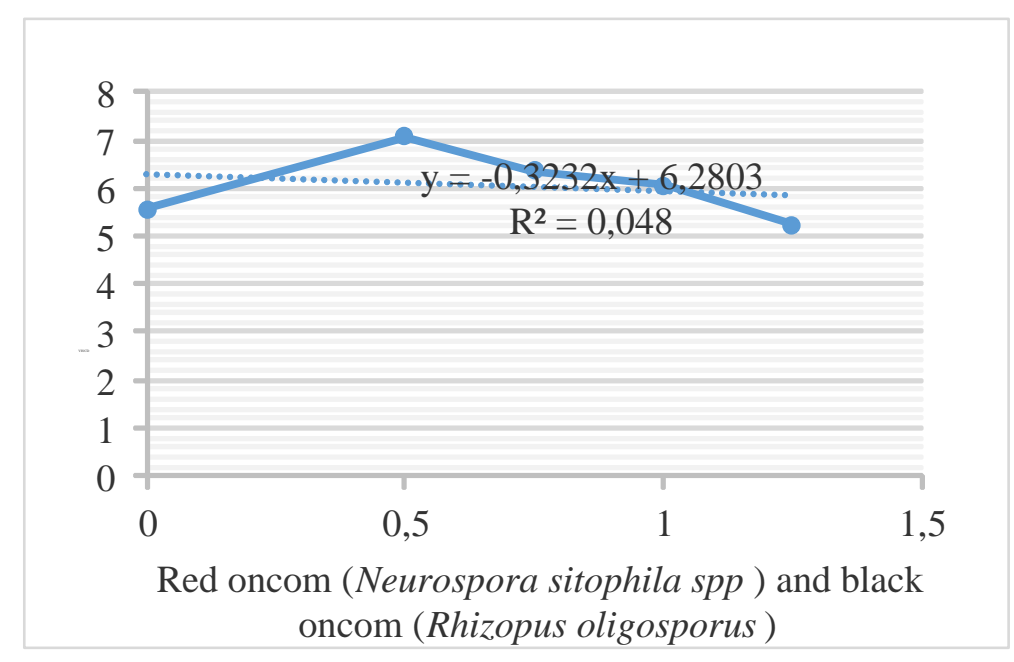

Figure 5. Effect of red oncom (Neurospora sitophila spp) and black oncom (Rhizopus oligosporus) on Villus height, $\mu \mathrm{m}$

CONCLUSION 
It can be concluded that red oncom (Neurospora sitophila spp) and black oncom (Rhizopus oligosporus) in feed gives a positive result on the broiler intestinal properties.

\section{ACKNOWLEDGEMENT}

The author would like to thanks to ministry and education that presented the paper funding using national scientific paper reward based on the research 2016. Furthermore, thanks to trader of oncom from Tasikmalaya that providing the red oncom and black oncom.

\section{REFERENCE}

Adli, D. N., \& Sjofjan, O. (2018). Nutrient content evaluation of dried poultry waste urea molasses block (DPWUMB) on In-vitro analysis. Sains Peternakan, 16(2), 50-53. https://doi. org/10.20961/sainspet.v16i2.21264

Adli, D. N., \& Sjofjan, O. (2020a). Growth performance, serum blood biochemistry, and intestinal properties of Arbor Acres Broiler fed diets containing mannan-riched fraction (MRF) and probiotic-enhanced liquid acidifier. Buletin Peternakan, 44(2), 96-105. https://doi.org/10.21059/bule tinpeternak.v44i2.54713

Adli, D. N., \& Sjofjan, O. (2020b). MetaAnalisis: pengaruh substitusi jagung dengan bahan pakal lokal terhadap kualitas karkas daging broiler. Jurnal Ilmu Peternakan Terapan, 3(2), 4448. https://doi.org/10.25047/jipt.v3i2. 1940

Adli, D. N., Sjofjan, O., \& Mashudi, M. (2017). Dried of poultry waste ureamolasses block (dpw-umb) as potential for feed supplementation. Jurnal Agripet, 17(2), 144-149. https:// doi.org/10.17969/agripet.v17i2.8391

Adli, D. N., Sjofjan, O., Natsir, M. H., \& Kusumaningtyaswati, A. (2020). Pengaruh kombinasi tepung kunyit (Curcuma domestica Val.) dan probiotik terhadap penampilan usus ayam pedaging. Jurnal Nutrisi Ternak Tropis Dan Ilmu Pakan, 2(1). https:// doi.org/10.24198/jnttip.v2i1.26587

Agustiningsih, D. (2002). Pengaruh Penggunaan Know, Dui Kitrucr Fermentasi Dengan Inokulum Tempe Dan Oncom Dalam Ransum Terhadap Performans Ayam Pedaging. Universitas Diponegoro.

Albright, S., Zappe, C., \& Winston, W. (2011). Data Analysis, Optimization, and Simulation Modeling. Cengage Learning.

Amalie, R. L. (2019). Pengaruh Pemberian Fermentasi Onggok-Ampas Tahu Dengan Jamur Oncom Merah Dalam Pakan Ayam Broiler Terhadap Bobot Usus dan Gizzard. Universitas Jenderal Soedirman.

Dinesh Babu, P., Bhakyaraj, R., \& Vidhyalakshmi, R. (2009). A low cost nutritious food "tempeh"-a review. In World Journal of Dairy \& Food Sciences (Vol. 4, Issue 1).

Hidanah, S., \& Widjaja, N. S. (2010). Pemanfaatan tepung limbah tempe fermentasi sebagai substitusi jagung terhadap daya cerna serat kasar dan bahan organik ayam pedaging jantan. Journal of Poultry Science, 3(1), 13-17.

Kasiman, M. R. (2019). Pengaruh Pemberian Fermentasi OnggokAmpas Tahu Menggunakan Jamur Oncom Merah Dalam Pakan Ayam Broiler Terhadap Konsumsi, Konversi dan Efisiensi Pakan. Universitas Jenderal Soedirman.

Koni, T. N., Bale-therik, J., \& Kale, P. R. (2013). Pemanfaatan kulit pisang hasil fermentasi Rhyzopus oligosporus dalam ransum terhadap pertumbuhan ayam pedaging. Jurnal Veteriner September, 14(3), 365-370.

Mahfudz, L. (2006). Pengaruh penggunaan ampas tahu fermentasi terhadap efisiensi penggunaan protein itik tegal jantan. Journal of the Indonesian Tropical Animal Agriculture, 2(31), 129-134. 
Putri, J. C., Lasmanawati, E., \& Setiawati, T. (2019). Pengenalan tentang masakan sunda di kalangan remaja Kecamatan Kiaracondong. Media Pendidikan, Gizi, Dan Kuliner, 8(1). https://doi. org/10.17509/boga.v8i1.19235

Sjofjan O., Adli D.N., Hanani P.K., \& Sulistiyaningrum D. (2020). The utilization of bay leaf (SyzygiumpolyanthumWalp) flour in feed on carcass quality, microflora instestine of broiler. International Journal of Engineering Technologies and Management Research, 6(11), 19. https://doi.org/10.29121/ijetmr.v6.i 11.2019.458

Sjofjan, O., Nur Adli, D., Djunaidi, I., \& Kuncoro, K. (2020). Utilization of biogas liquid waste for starter in the fermentation of rice husk as a potential feed for poultry. Animal Production, 22(1), 24-30. https://doi.org/10.20884 /1.jap.2020.22.1.38

Sujono. (2001). Tampilan Produksi Telur, Produksi Karkas dan Kualitas Semen Ayam Arab yang diberi Pakan
Mengandung Berbagai Aras Bekatul Fermentasi dengan Rhizopus oligosporus. Universitas Airlangga.

Vital, R., Bassinello, P., Cruz, Q., Carvalho, R., de Paiva, J., \& Colombo, A. (2018). Production, quality, and acceptance of tempeh and white bean tempeh burgers. Foods, 7(9), 136. https://doi.org/10.3390/foods7090136

Widiyawati, I., Sjofjan, O., \& Adli, D. N. (2020). Peningkatan kualitas dan persentase karkas ayam pedaging dengan subtitusi bungkil kedelai menggunakan tepung biji asam (Tamarindus indica L) fermentasi. Jurnal Nutrisi Ternak Tropis, 3(1), 35-40. https://doi.org/10.21776/ub.jnt .2020 .003 .01 .7

Zaman, Q., Suparno, G., \& Hariani, D. (2013). Pengaruh kiambang (salvinia molesta) yang difermentasi dengan ragi tempe sebagai suplemen pakan terhadap peningkatan biomassa ayam pedaging. LenteraBio: Berkala Ilmiah Biologi, 2(1). 